\title{
TOKSISITAS EKSTRAK METANOL DAUN KOLOWE (CHYDENANTHUS EXCELSUS)
}

\author{
Indah Puspa Dewi*, Victoria Yulita, Laode Rijai \\ Laboratorium PenelitiandanPengembangan FARMAKA TROPIS \\ FakultasFarmasiUniversitasMulawarman, Samarinda, Kalimantan Timur \\ *Email : indre.0852@gmail.com
}

\begin{abstract}
ABSTRAK
Pemanfaatan bahan alam sebagai sumber bahan obat telah dilakukan untuk meningkatkan mutu kehidupan masyarakat. Secara empiris kolowe digunakan oleh masyarakat buton sebagai racun ikan untuk di konsumsi. Penelitian ini bertujuan untuk mengetahui toksisitas ekstrak metanol daun kolowe. Metode yang digunakan adalah Brine Shrimp Letality (BSLT). Uji toksisitas dilakukan dengan menggunakan larva udang Artemia salina Leach yang berumur 48 jam. Efek toksik diidentifikasi dengan presentase kematian larva udang menggunakan analisis probit $\left(\mathrm{LC}_{50}\right)$. Hasil pengujian menunjukkan bahwa ekstak metanol daun kolowe bersifat toksik $\left(\mathrm{LC}_{50}=237,85 \mathrm{ppm}\right)$.
\end{abstract}

Kata Kunci: Daun Kolowe, Brine Shrimp Letality, LC $_{50}$.

\begin{abstract}
Utilization of natural materials as a source of medicine have been made to improve the quality of people's lives. Empirically kolowe used by people in Buton as a fish poison for consumption. This study aims to determine the toxicity of methanol extract of leaves kolowe. The method used is the Brine Shrimp Letality (BSLT). Toxicity tests performed using larval shrimp Artemia salina Leach was 48 hours. The toxic effect is identified with death rates that shrimp larvae using probit analysis (LC50). The test results showed that the methanol ekstak kolowe leaves are not toxic $($ LC50 $=237.85 \mathrm{ppm})$.
\end{abstract}

\section{PENDAHULUAN}

Indonesia merupakan negara yang terletak disalah satu kawasan tropis yang kaya akan keaneka ragaman hayati. Salah satu tumbuhan yang dimanfaatkan oleh masyarakat khususnya masyarakat Buton adalah Kolowe (Chydenantus excelsus). Kolowe (Chydenantus excelsus) merupakan tumbuhan yang banyak tumbuh di daerah pesisir pantai. Masyarakat Buton menggunakan biji kolowe untuk membunuh ikan, namun tidak menyebabkan keracunan pada masyarakat yang mengkonsumsi ikan tersebut. Tanaman kolowe yang akan di teliti adalah bagian daunnya. Untuk itu, peneliti ini mengetahui potensi bioaktivitas dari daun kolowe. Adapun bioaktivitas yang akan di teliti adalah uji toksisitas dengan menggunakan metode Brine Shrimp Lethality Test (BSLT). Penggunaan empiris dalam masyarakat Buton menggunakan tanaman kolowe (Chydenantus excelsus) sebagai racun ikan serta kurangnya publikasi ilmiah tentang pengujian toksistas tanaman ini di Indonesia, melatar belakangi dilakukan penelitian tentang aktivitas antioksidan dan toksisitas ekstak daun kolowe ini. 


\section{METODE PENELITIAN}

Brine Shrimp Lethality Test (BSLT) merupakan salah satu metode untuk menguji bahan-bahan yang bersifat toksik dan digunakan sebagai suatu bioassay yang pertama untuk penelitian bahan alam. Metode ini menggunakan larva Artemia salina Leach sebagai hewan coba. Uji toksisitas dengan metode BSLT ini merupakan uji toksisitas akut dimana efek toksik dari suatu senyawa ditentukan dalam waktu singkat, yaitu rentang waktu selama 24 jam setelah pemberian dosis uji. Suatu ekstrak dikatakan toksik berdasarkan metode BSLT jika harga $\mathrm{LC} 50<1000 \mu \mathrm{g} / \mathrm{ml}$

\section{Bahan}

Bahan-bahan yang digunakan dalam penelitian ini adalah Daun kolowe sebagai sampel, air laut untuk media penetasan dan pertumbuhan hewan uji, metanol sebagai pelarut, kista Artemia salina L, dan ragi sebagai pakan untuk hewan uji.

\section{Peralatan}

Alat yang digunakan dalam penelitian ini adalah aerator digunakan untuk menyuplai $\mathrm{O}_{2}$ untuk biakan hewan uji, batang pengaduk untuk mengaduk ekstrak, bejana maserasi untuk tempat maserasi, corong untuk menuangkan cairan, wadah pembiakan hewan uji, vial sebagai wadah pengujian, dan pipet tetes untuk mengambil cairan.

\section{Prosedur}

\section{Ekstraksi Sampel}

Sampel dipotong kecil-kecil kemudian direndam dengan metanol dalam bejana maserasi kemudian ditutup dan dibiarkan selama 24 jam dan terlindung dari cahaya matahari, kemudian disaring. Ampas direndam lagi dengan metanol dan dibiarkan selama 24 jam. Penyarian dilakukan terus menerus hingga pelarut jernih. Ekstrak metanol hasil penyaringan kemudian diuapkan hingga memperoleh ekstrak kolowe pekat.

\section{Brine Shrimp Lethality Test (BSLT)}

Disiapkan larva udang yang telah berumur 2 hari sebagai hewan uji. Kemudian disiapkan konsentrasi sampel uji dengan variasi konsentrasi 20 ppm,40 ppm, 60 ppm,80 ppm, dan 100 ppm dalam $10 \mathrm{~mL}$. Larva Artemia salina Leach dimasukkan sebanyak 10 ekor ke dalam vial dan di tambahkan ragi sebagai pangan kemudian di tambahkan dengan variasi konsentrasi sampel uji dan di tambahkan air laut sampai $10 \mathrm{~mL}$. Kemudian vial didiamkan dibawah sinar lampu selama 24 jam dan diamati jumlah larva yang mati.

\section{HASIL DAN PEMBAHASAN}

Dibawah ini adalah data hasil pengujian toksisitas ekstrak metanol daun kolowe (Chydenanthus excelsus) terhadap larva udang Artemia salina 


\begin{tabular}{|c|c|c|c|c|c|c|}
\hline \multirow{2}{*}{$\begin{array}{c}\text { Replikasi } \\
\text { sampel }\end{array}$} & \multicolumn{7}{|c|}{ Jumlah larva yang mati } \\
\cline { 2 - 7 } & $20 \mathrm{ppm}$ & $40 \mathrm{ppm}$ & $60 \mathrm{ppm}$ & $80 \mathrm{ppm}$ & $100 \mathrm{ppm}$ & Kontrol \\
\hline 1 & 2 & 0 & 1 & 3 & 3 & 2 \\
\hline 2 & 1 & 1 & 4 & 1 & 3 & 1 \\
\hline 3 & 1 & 2 & 2 & 3 & 3 & 0 \\
\hline 4 & 0 & 1 & 2 & 3 & 2 & 0 \\
\hline 5 & 0 & 1 & 0 & 3 & 3 & 0 \\
\hline $\begin{array}{c}\text { Total } \\
\text { penghambatan }\end{array}$ & 4 & 5 & 9 & 13 & 14 & 3 \\
\hline $\begin{array}{c}\% \\
\text { penghambatan }\end{array}$ & $2 \%$ & $2,6 \%$ & $12 \%$ & $20 \%$ & $22 \%$ & - \\
\hline Harga Probit & 2,9463 & 3,4452 & 3,8250 & 4,1684 & 4,2278 & - \\
\hline
\end{tabular}

\begin{tabular}{|c|c|c|}
\hline Log Konsentrasi (x) & Harga Probit (y) & Konsentrasi \\
\hline 1,30 & 2,9463 & 20 \\
\hline 1,60 & 3,4452 & 40 \\
\hline 1,77 & 3,8250 & 60 \\
\hline 1,90 & 4,1684 & 80 \\
\hline 2 & 4,2278 & 100 \\
\hline
\end{tabular}

Uji toksisitas terhadap Artemia salina dengan ekstrak metanol daun kolowe dilakukan dengan 5 kali replikasi pada masing-masing konsentrasi 20,40,60,80, dan 100 ppm. Dari tabel diatas dapat kita lihat bahwa terjadi peningkatan persen kematian seiring dengan meningkatnya konsentrasi sampel uji.

Grafik log konsentrasi dan mortalitas probit uji toksisitas ekstrak kolowe terhadap Artemia salina dapat kita lihat pada grafik dibawah ini

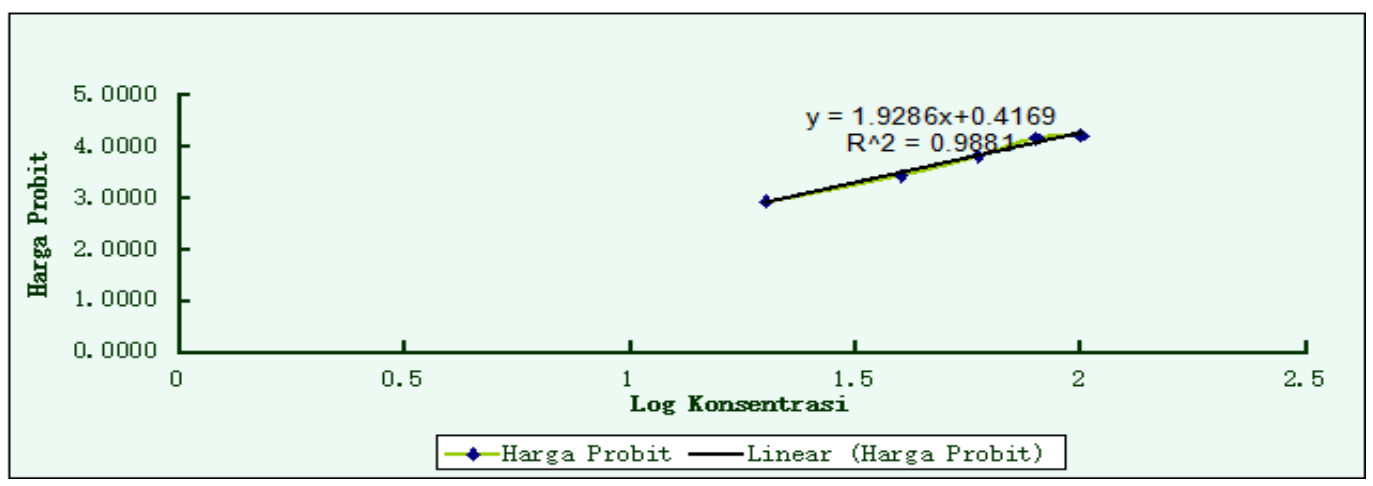

Grafik diatas merupakan hubungan antara log konsentrasi dengan nilai probit. Berdasarkan grafik tersebut menunjukkan bahwa 20, 40, 60,80, dan 100 ppm menunjukkan peningkatan nilai probit.

\section{KESIMPULAN}

Sampel kolowe menghasilkan nilai $\mathrm{LC}_{50}$ sebesar 237,85 ppm. Sampel dikatakan toksik jika nilai $\mathrm{LC}_{50}<1000$ ppm 


\section{DAFTAR PUSTAKA}

1. Anderson, J. E., Goetz C.M., Mc Laughlin J. L. 1 991. A Blind Comparison of Simple Bench-top Bioassay and Human Tumor Cell Cytotoxicities as Antitumor Prescrenss, Natural Product Chemistry, Elseiver, Amsterdam

2. Helmi, Henny. 2008. Uji Toksisitas Kolowe (Chydenanthus excelsus) dengan menggunakan metode BSLT. Jurnal Sumberdaya Perairan Volume 1 Edisi 2.

3. Watson, David G. 2009. Analisis Farmasi. EGC: Jakarta 